\title{
PERAN UNIVERSITAS MUHAMMADIYAH KUPANG DALAM PENGEMBANGAN PENDIDIKAN ISLAM
}

\author{
Anton \\ Fakultas Agama Islam Universitas Muhammadiyah Kupang \\ antonbima67@gmail.com
}

\begin{abstract}
Abstrak
Universitas Muhammadiyah Kupang adalah salah satu Perguruan Tinggi Islam yang terkenal dan terbesar yang berdiri sejak tahun 1987 di Wilayah Nusa Tenggara Timur. Kehadiranya memberikan angin segar bagi umat muslim diwilayah tersebut, karena dapat memberikan kontribusi yang terbaik untuk pengembangan pendidikan Islam. Tidak hanya diminati oleh umat muslim saja akan tetapi yang lebih menarik adalah umat non-muslim lebih beranimo untuk masuk ke Perguruan Tinggi Islam tersebut. Padahal disekitar perguruan tersebut telah berdiri sejak lama, terbesar dan terkenal yaitu perguruan tinggi yang bernaung langsung dibawah agama Katolik dan Protestan.Penelitian ini bertujuan untuk mengetahui konsep pengembangan serta peran Universitas Muhammadiyah Kupang terhadap pengembangan pendidikan Islam.Hasil penelitian menunjukan bahwa UniversitasMuhammadiyah Kupang didirikan bukan hanya untuk orang Muhammadiyah atau Islam tetapi yang lebih penting adalah untuk kaum dhuafah, orang miskin dan untuk umat semua umat di Nusa Tenggara Timur, yang menekankan konsep rahmatan lil aalamin dan konsep organisme yaitu merujuk pada al-qur'an dan hadits serta ijma dalam proses pengembangan Pendidikan Islam.
\end{abstract}

Kata Kunci:Perguruan Tinggi, Pengembangan dan Pendidikan Islam

\section{Pendahuluan}

$\mathrm{P}$ roses pendidikan, sebenarnya telah berlangsung sepanjang sejarah dan berkembang sejalan dengan perkembangan sosial budaya manusia di permukaan bumi. Khusus pendidikan Islam, berlangsung sejak agama Islam itu sendiri didakwahkan oleh Nabi Muhammad saw. Pendidikan Islam yang berlangsung di zaman Nabi Muhammad saw. dan beliau juga bertindak sebagai guru atau pendidik utama ketika itu, telah mengalami perkembangan yang cukup signifikan. Sepeninggal Nabi Muhammad saw. Pendidikan Islam semakin berkembang seiring dengan semakin meluasnya wilayah Islam ke seluruh penjuru, termasuk di kepulauan Nusantara, Indonesia.Universitas Muhammadiyah Kupang di Nusa Tenggara Timur berdiri pada tahun 1978, dalam sense sejarah dan eksistesinya merupakan lembaga pendidikan Islam modernyang dikelolah secara profesional, telah memberikan kontribusi signifikan dalam pembaruan dan pengembangan pendidikan umum maupun Islam di Nusa Tenggara Timur. Dalam hubungan pembaruan pendidikan Islam tersebut, Azyumardi Azra 
mengemukakan bahwa gagasan modernisme Islam menemukan momentumnya sejak awal ke-20, pada lapangan pendidikan direalisasikan dengan pembentukan lembaga pendidikan modern. ${ }^{1}$

Kemudian dalam kaitannya dengan pengembangan pendidikan Islam, kehadiran Perguruan Tinggi Muhammadiyah Kupang juga memiliki peran penting. Hal ini bila dimaknai istilah pengembangan pendidikan Islam sebagai perubahan yang baru, dan disengaja untuk meningkatkan kemampuan guna mencapai tujuan tertentu,maka Universitas Muhammadiyah Kupang,dalam hal ini telah mengadakan perubahan yang lebih maju, sebab Perguruan Tinggi Muhammadiyah Kupang adalah perguruan tinggi Islam yang visinya adalah mengembangkan ilmu pengetahuan, juga berupaya meningkatkan iman dan taqwa mahasiswanya. ${ }^{2}$ Keberadaan Perguruan Tinggi Muhammadiyah Kupang, jelas lebih mengutamakan pengembangan pendidikan Islam dan pendidikan umum di NTT. hal ini dibuktikan bahwa Perguruan Tinggi Muhammadiyah Kupang memberikan pelayanan kepada masyarakat NTT tanpa mengenal adat, ras, suku dan agama, hampir 70\% mahasiswanya beragama non muslim sedangkan $30 \%$ beragama muslim.

Universitas Muhammadiyah Kupang memiliki 6 Fakultas antara lain Fakultas Agama Islam, Fakultas Keguruan dan Ilmu Pendidikan, Fakultas Ilmu Sosial, Fakultas Ekonomi dan Perikanan dengan mengikuti sistem pembelajarannya dilaksanakan secara klasikal dan modern. Lebih dari itu, beberapa segi pengembangan pendidikan yang digalakkan Perguruan Tinggi Muhammadiyah Kupang selama ini, dapat dilihat pada aspek kelembagaan, kurikulum, dan metodologi pengajaran.Beberapa aspek pengembangan dalam pendidikan Islam yang diperankan Perguruan Tinggi Muhammadiyah Kupang selama ini, terutama dalam aspek organisasi kelembagaan, metode pengajaran, dan kurikulum lebih mengutamakan nilai-nilai dakwah dan pendidikan Islam untuk kemajuan Islam di NTT hal ini penting untuk ekspor lebih lanjut dengan harapan dapat memberikan kontribusi kepada Perguruan Tinggi Islam lain khususnya di NTT untuk lebih mengutamakan nilai-nilai dakwah dan pendidikan Islam.

\section{Tinjuan Makna Pendidikan Islam}

Istilah pendidikan dalam bahasa Yunani, adalah paedagogie, terdiri atas dua suku kata, yakni paes dan $a g o^{3}$.Dari kata ini, dipahami bahwa pendidikan merupakan kegiatan belajar mengajar, dan unsur-unsur terpenting di dalamnya adalah sistem pendidikan, tujuan pendidikan, materi pendidikan, sistem

1 Azyumardi Azra,Esei-esei Intelektual Muslimdan Pendidikan Islam (Jakarta: Logos Wacana Ilmu, 2008), 90.

${ }^{2}$ Profil Perguruan Tinggi Muhammadiyah Kupang: 2013, 2-5.

${ }^{3}$ AbuAhmadi, Ilmu Pendidikan (Cet.I; Jakarta: Rineka cipta, 2009), 69 
pendidikan, sarana dan prasarana pendidikan, cara penilaian dalam pendidikan dan seterusnya.Untuk lebih memahami bagaimana pendidikan Islam tersebut, maka berikut ini dikemukakan beberapa definisi :

a. Yusuf al-Qardawi menyatakan pendidikan Islam adalah sebagai pendidikan manusia seutuhnya, akal dan hatinya, rohani dan jasmaniyah, akhlak dan keterampilannya, dan menyiapkan untuk menghadapi masyarakat dengan segala kebaikan dan kejahatannya, manis dan pahitnya ${ }^{4}$.

b. Hasan Langgulung menyatakan, pendidikan Islam adalah sebagai proses penyiapan generasi muda untuk menjadi peranan, memindahkan pengetahuan dan nilai-nilai Islam yang diselaraskan dengan fungsi manusia untuk beramal di dunia dan memetik hasilnya di akhirat. ${ }^{5}$

Berdasarkan pendapat para ahli tersebut penulis dapat memahami bahwa pendidikan Islam merupakan proses pembentukan individu berdasarkan ajaranajaran Islam. Melalui proses pendidikan itu, individu dibentuk agar dapat mencapai derajat yang tinggi dan sempurna (insan kamil).

\section{Konsep Pengembangan Pendidikan Islam}

Terdapat tiga konsep dan paradigma pengembangan pendidikan Islam, sebagai berikut

\section{a. Konsep Formisme}

Dalam konteks pendidikan Islam, masih ditemukan pemahaman paradigma formisme yang memandang adanya dikotomi atau diskrit. Segala sesuatunya dilihat dari dua sisi yang berlawanan, seperti laki-laki dan perempuan, ada dan tidak ada, bulat dan tidak bulat, madrasah dan non madrasah, pendidikan agama dan pendidikan umum, demikian seterusnya. Pandangan yang dikotomis tersebut pada giliran selanjutnya mengalami pengembangan dalam melihat dan memandang aspek kehidupan dunia, dan akhirat, kehidupan jasmani dan rohani sehingga pendidikan Islam hanya diletakkan pada aspek kehidupan akhirat saja atau kehidupan rohani saja. Dengan demikian, pendidikan keagamaan dihadapkan dengan pendidikan non-keagamaan, pendidikan keislaman dan nos-keislaman, pendidikan agama dan pendidikan umum.Karena itu, pengembangan pendidikan Islam hanya berkisar pada aspek kehidupan ukhrawi yang terpisah dengan kehidupan duniawi, atau aspek kehidupan rohani yang terpisah dengan kehidupan jasmani. ${ }^{6}$ Pandangan dikotomis inilah yang menimbulkan dualisme dalam sistem

\footnotetext{
${ }^{4}$ Yusuf Al-Qardhawi, Pendidikan Islam dan Madrasah terjemahan Bustani A. Gani dan Ahmad, Zainal Ilmu Pendidikan (Jakarta: Bulan Bintang,2008), 39. 1990), 94

${ }^{5}$ Hasan Langgulung, Beberapa Pemikiran tentang Pendidikan Islam(Bandung: al-Ma'arif,

${ }^{6}$ Muhaimin, Paradigma Pendidikan Islam; Upaya Mengefektifkan Pendidikan Agama Islam di Sekolah.(Cet. II; Bandung: PT. Remaja Rosdakarya, 2009), 39-40.
} 
pendidikan.Istilah pendidikan agama dan pendidikan umum, atau ilmu agama dan ilmu umum sebenarnya muncul dari paradigma formisme tersebut.

Menurut penulis, ilmu apapun namanya, jika ia diletakkan dalam wadah yang islami, maka ilmu tersebut adalah "ilmu Islam" dan di luar itu tidak islami. Kalaupun memang sudah terlanjur ada pencaplokan bahwa ilmu-ilmu semisal fisika, ilmu sosial, ilmu humaniora, dan selainnya merupakan "ilmu Barat", maka sebagai solusinya diperlukan pengembangan rumusan yang mapan tentang islamisasi sains. Islamisasi sains diinterprerasikan sebagai integrasi ilmu dengan wahyu, yakni memformat segala jenis ilmu pengetahuan berdasarkan nilai-nilai Islam.Karena itu, islamisasi sains, juga diterminologikan sebagai islamisasi ilmu pengetahuan yang dalam implementasinya menghilangkan konsep-konsep sekuler yang tidak islami di setiap persoalan yang berkaitan dengan pendidikan.

\section{b. Konsep Mekanisme}

Selain konsep formisme yang telah dijelaskan secara luas, ditemukan pula adanya paradigma mekanisme.Dalam aspek ini, paradigma mekanisme dalam pendidikan dipandang sebagai pengembangan seperangkat nilai kehidupan.Aspekaspek atau nilai-nilai kehidupan itu sendiri, terdiri atas nilai agama, nilai individu, nilai sosial, nilai rasional dan lain-lain. ${ }^{7}$ Dalam perspektif pendidikan Islam, umat Islam dididik dengan seperangkat ilmu pengetahuan atau mata pelajaran, salah satunya adalah mata pelajaran pendidikan agama yang mempunyai fungsi tersendiri, yaitu sebagai (1) pengembangan dan peningkatan keimanan dan ketaqwaan; (2) penyaluran bakat dan minat dalam mendalami agama; (3) perbaikan kesalahan, kekurangan dan kesalahan dalam keyakinan; (4) pencegahan hal-hal negatif dari lingkungannya atau budaya asing yang berbahaya; (5) sumber nilai atau pedoman hidup untuk mencapai kebahagiaan dunia dan akhirat; (6) pengajaran atau penyampaian pengetahuan keagamaan. Jadi pendidikan agama lebih menonjolkan fungsi moral dan spiritual, atau dimensi efektif daripada kognitif dan psikomotor, dalam arti dimensi kognitif dan psikomotor diarahkan untuk pembinaan efektif (moral dan spiritual), yang berbeda dengan mata pelajaran lainnya.

Sebagai implikasinya, pengembangan pendidikan Islam dalam arti pendidikan agama tersebut bergantung pada kemauan dan kemampuan dari para pembinanya dan sekaligus pimpinan dari lembaga pendidikan tersebut, terutama dalam membangun hubungan kerjasama dengan mata pelajaran (kuliah) lainnya.Hubungan (relasi) antara pendidikan agama dengan beberapa mata pelajaran atau mata kuliah lainnya dapat bersifat horizontal-lateral (independent), lateral-sekuensial, atau vertikal linier.Dengan adanya relasi yang bersifat horizontal-lateral (independent) mengandung arti bahwa beberapa mata pelajaran

${ }^{7}$ Muhaimin, Paradigma Pendidikan Islam ...,39-40. 
(mata kuliah) yang ada dan pendidikan agama mempunyai hubungan sederajat yang independent, dan tidak harus saling berkonsultasi. Relasi yang bersifat lateral skuensial, berarti di antara masing-masing mata pelajaran (mata kuliah) tersebut mempunyai relasi sederajat yang saling berkonsultasi. Sedangkan relasi vertikal-linier berarti mendudukkan pendidikan agama sebagai sumber nilai atau sumber konsultasi, sementara seperangkat mata pelajaran (mata kuliah) yang lain adalah termasuk pengembangan nilai-nilai insani yang mempunyai relasi vertikallinier dengan agama.

\section{c. Konsep Organisme}

Konsep organisme yang bertolak dari pandangan bahwa pendidikan Islam adalah kesatuan atau sebagai sistem yang terdiri atas komponen-komponen yang rumit, yang berusaha mengembang-kan pandangan semangat hidup, yang dimanifestasikan dalam sikap hidup dan keterampilan hidup yang Islami.Dalam konteks pandangan semacam itu, pengembangan pendidikan Islam harus sesuai dengan doktrin Alquran dan sunnah sebagai sumber pokok, kemudian mau menerima kontribusi pemikiran dari para ahli serta mempertimbangkan konteks historisitasnya. Karena itu, nilai Ilahi (agama) didudukkan sebagai sumber konsultasi yang bijak, sementara aspek-aspek kehidupan lainnya didudukkan sebagai nilai-nilai insani yang mempunyai relasi horizontal-lateral atau lateralsekuensial, tetapi harus berhubungan vertikal-linier dengan Ilahi (agama). Melalui upaya itu, maka sistem pendidikan Islam diharapkan dapat mengintegrasikan nilai-nilai ilmu pengetahuan, nilai-nilai agama dan etik, serta mampu melahirkan manusia-manusia yang menguasai ilmu pengetahuan dan teknologi, memiliki kematangan profesional, dan sekaligus hidup di dalam nilai-nilai agama. Model paradigma pengembangan pendidikan yang disebutkan ini, nampaknya mulai dikembangkan di madrasah. ${ }^{8}$

Perdebatan disekitar ada atau tidaknya pendidikan Islam, tanpa masih menjadi persoalan hangat dikalangan para pemikir pendidikan Islam.Islam sebagai system nilai universal dan diyakini mutlak kebenarannya seharusnya memberikan paradigm filosofis dan teologi terhadap pendidikan Islam itu sendiri. Tetapi sayangnya pengertian pendidikan Islam yang berkembang dalam masyarakat baru sekedar menerapkan etika Islam dalam pemanfaatannya atau lebih sederhana lagi sebagai sebuah nama dari lembaga pendidikan yang dikelola oleh kaum muslimin. Padahal yang namanya pendidikan Islam seharusnya mengejewantakan nilai-nilai Islam dalam pendidikan baik secara ontology, epistemology dan aksiologisnya. ${ }^{9}$

\footnotetext{
${ }^{8}$ Muhaimin, Paradigma Pendidikan Islam ..., 40.

${ }^{9}$ Tobroni, Pendidikan Islam; Paradigm Teologis, Filosofis Dan Spiritualitas (Malang: UMM Press Malang, 2008), 13
} 
Pendapat ini sejalan dengan sebagian temuan penulis menemukan bahwa sebagian dari para pengelola Perguruan Tinggi Islam masih ada yang belum paham tentang konsep pendidikan islam yang sebenarnya sehingga dalam pelaksanaannya hanya pada sebatas pengetahuan sementara pada tataran implementasinya masih kurang. Hal ini dapat diperhatikan secara bersama, apabila para pemimpin atau penglola Perguruan Tinggi Islam memahami pendidikan islam secara implisit pasti dalam suasana proses kegiatan belajar mengajar minimal dapat mengejewantakan nilai-nilai islam kedalam kegiatan tersebut, akan tetapi kebanyak sebagian pengelola bahkan para pendidikan terutama pendidikan non kependidikan Islam, kurang memperhatikan nilai-nilai pendidikan islam yang terkandung dalam proses belajar mengajarnya.

Beni Ahmad Saebani berpendapat bahwa memahami pendidikan Islam tidak semudah menguraikan kata "Islam" dari kata "pendidikan" karena selain sebagai predikat, Islam merupakan satu subtansi dan subjek penting yang cukup kompleks. Oleh karena itu untuk memahami pendidikan Islam perlu melihat aspek utama misi agama Islam yang diturunkan kepada umat manusia secara pedagogis. Islam sebagai ajaran yang dating dari allah yang merefleksikan nilainilai pendidikan yang mampu membimbing dan mengarahkan manusia sehingga menjadi manusia sempurna. Islam sebagai agama universal telah memberikan pedoman hidup bagi manusia menuju kehidupan bahagia, yang capaiannya bergantung pada pendidikan. ${ }^{10}$ Pembaharuan dalam dunia Islam sudah dimulai oleh tokoh cendekiawana Islam seperti Ibnu Taimiyah, Al-afghani, Muhammad Abduh, Rasyid Ridha, Fajlur Rahman dan pemikir lainnya. Buah pemikiran tokoh-tokoh Islam ini mempunyai pengaruh besar pada perubahan pola pendidikan Islam dan cara pengalamannya. Memperbarui pemahaman keagamaan (keIslaman) yang masih bersifat ortodoks/kolot dan dikotomis.Paling tidak para cendekiawan tersebut sebagia salah satu contoh bagi para pendidik untuk dapat diikuti jejaknya.

Sejalan dengan pendapat Ahmad Tafsir"1 menyatakan bahwa "Pendidikan Islam sebagai bimbingan yang diberikan oleh seseorang agar ia berkembang secara maksimal sesuai dengan ajaran Islam atau dengan kata lain pendidikan Islam adalah bimbingan terhadap seseorang agar ia menjadi seorang muslim semaksimal mungkin. Ahmad Tafsir menekan pada sifat dari aktifitas pendidikan Islam yaitu berupa bimbingan sebagai suatu upaya yang tidak hanya ditekankan kepada aspek pengajaran/transfer ilmu pengetahuan, tetapi berupa arahan, bimbingan, pemberian petunjuk dan pelatihan menuju terbentuknya pribadi muslim yang seutuhnya".

\footnotetext{
${ }^{10}$ Beni Ahmad Saebani, dkk.,Ilmu Pendidikan Islam (Bandung: Cv.Pustaka Setia,2009),5.

${ }^{11}$ Ahmad Tafsir, ,Ilmu Pendidikan Dalam Perspektif Islam (Bandung PT Remaja Rosda,2006), 32.
} 
Hemat penulis, pendidikan Islam sangatlah urgen dalam dunia pendidikan, karena melalui pendidikan Islam seseorang yang belum mendapatkan petunjuk untuk mengapai tujuan hidupnya sebagai hamba Allah yang hanya untuk beribadah kepadanya dapat terpenuhi. Dan dalam menjalankan tugasnya sebagai khalifah di muka bumi baik ia sebagai pendidik, non kependidikan dan apapun jenis profesinya dapat dijalankan dengan baik sesuai yang digariskan dalam petunjuk yang telah dititipkan yaitu al-qur'an dan hadits. Lebiha lanjut, dalam Pemikiran Fazlur Rahman (1919) yang menyuguhkan analisis perkembangan pendidikan Islam dan merumuskan alternative metodologi pemikiran keIslaman sebagai rumusan jalan keluar dari seluruh kritisisme atas sejarah pemikiran keIslaman yang cenderung konservatif untuk memujudkan masyarakat Islam sebagai competitor dipentas global memerlukan sarana penunjang yaitu perubahan pada system kelembagaan pendidikan Islam. sistem pendidikan Islam terlebih dahulu harus dimodernisasi atau diperbaharui.FazlurRahmameniscayakan bahwa rakyat di negara Islam mempunyai kekuasaan untuk menerjemahkan teks AlQur'an guna merancang undang-undang untuk kemaslahatan umatnya.Kedaulatan Allah SWT dalam kiblatnya tidak bisa dipandang sebagai sesuatu yang absolut atau kaku. Sebab dalam al-Qur'an memiliki konsekwensi berupa perlunya suatu kerangka pembaharuan dalam rangka mengungkapkan ajaran-ajaran moral yang ada didalamnya

Konsep pendidikan Islam yang diperankan Universitas Muhammadiyah Kupang memang sejalan dengan pendapat Fazlur Rahman, karena Perguruan Tinggi Muhammadiyah Kupang selalu merujuk dan mengkaji Al-Qur'an dan Hadits serta menjadikan ijtihad para ulama sebagai dasar pijakan penetapan dan pengambilan keputusan pada setiap masalah yang sedang dihadapinya. Salah satu contoh yang dilakukan adalah mengembangkan pendidikan Islam melalui dakwah, pembinan dan pengajaran, penelitian dan pengabdian pada masyarakat, meningkatkan kerjasama dengan instansi-instansi pemerintah dan setiap komponen-komponen yang dilakukan tersebut tidak terlepas dari sumber utama yaitu Al-Qur'an dan Hadits. Dengan memperhatikan konsep ini, hemat penulis bahwa Perguruan Tinggi Muhammadiyah Kupang memahami konsep pengembangan pendidikan Islamnya dengan konsep organisme, konsep organisme yang dimaksud adalah memandang bahwa pendidikan Islam adalah satu kesatuan atau sebagai system yang terdiri atas komponen-komponen yang rumit, yang berusaha mengembangkan padangan semangat hidup, yang dimanifestasikan dalam sikap hidup dan keterampilan hidup yang Islam dalam konteks pandangan tersebut pengembangan pendidikan Islam harus sesuai dengan doktrin Al-Qur'an dan Hadits sebagai sumber pokok, kemudian menerima kontribusi pemikiran para ahli serta mempertimbangkan konteks historisnya, karena itu nilai ilahi didudukan sebagai sumber konsultasi yang bijak, sementara aspek-aspek kehidupan lainnya 
didudukan sebagai nilai-nilai insani yang mempunyai relasi horizontallatera/lateral-sekunsial tetap harus berhubungan dengan vertical-linear dengan ilahi/agama. ${ }^{12}$

Selain mengembangkan konsep organisme, konsep lain yang seirama juga perlu diperhatikan oleh Perguruan Tinggi Islam dalam mengembangankan pendidikan Islam. hemat penulis Perguruan Tinggi Islam perlu memprioritaskan konsep pengembangan pendidikan Islam modern salah satu konsep yang ditawarkan adalah reorentasi pendidikan Islam modern, sebagaimana yang dikutip Ikhlas (2015) dalam Jurnal Ilmiah Kreatif; beberapa point tentang pengembangan pendidikan Islam modern diantaranya reorentasi pendidikan Islam dengan kutipan pendapat Malik Fadjar menyampaikan kritik kepada pendidikan yang diterapkan oleh lembaga pendidikan Islam seperti pondok pesantren yang monoton pada agama dan sangat berbeda dengan model sekolah Negara haruslah dirubah dengan sistem pendidikan terpadu, yakni memadukan ilmu agama dengan system pendidikan umum. Dengan demikian lembaga pendidikan Islam akan menghasilkan output yang matang dalam agama dan memiliki semangat patriotism. $^{13}$

Begitu juga dengan Perguruan Tinggi harus menerapkan pola Perguruan Tinggi yang mengabungkan antara pola Perguruan Tinggi umum dan Islam dengan mengadopsi pendidikan model barat, karena sistem dipandang terbaik dan disempurnakan dengan penambahan mata kuliah kearifan local (local wisdom) dengan mengIslamkan berbagai segi kehidupan yang tidak Islami. Agama Islam tidak diarahkan kepada pemahaman mistis melainkan menghadapi dunia secara realistis. Salah satu sarana yang untuk melakukan upaya pembaharuan atau mereorintasi pendidikan dapat menjadikan Muhammadiyah dan Nahdatul Ulama (NU) sebagai objek kajiannya khusus pada orientasi wawasan pendidikan Islam di Indonesia, sebab kedua organisasi tersebut merupakan ormas Islam terbesar di Indonesia dan cukup representative untuk dijadikan bahan analisis dalam kerangka pembaharuan pendidikan yang ada dinegeri ini.

Malik Fadjar yang dikutip Ikhlas mengatakan bahwa beberapa gagasan reoriantasi serta rancangan pendidikan Islam agar ada perubahan yang berarti dimasa depan dalam rangka mewujudkan pendidikan Islam yang bermartabat untuk perubahan hidup yang berkarakter melalui pola pendidikan diantarannya adalah:

${ }^{12}$ Muhaimin, Paradigma Pendidikan Islam; Upaya Mengefektifkan Pendidikan Agama Islam di Sekolah (Cet. II; Bandung: PT. Remaja Rosdakarya,2009), 39-40.

${ }^{13}$ Malik Fadjar, Holistika Pemikiran Pendidikan (Jakarta: Raja Grafindo Persada, 2006), 24.Yang dikutip oleh Ikhlas "Konsep Pengembangan Pendidikan Islam Modern" dalam Jurnal Ilmiah Kreatif, Volume XII Nomor 2 edisi Juli 2015 Ber-ISSN 0216-7794: IAIM Bima. 


\section{Menjadikan Islam sebagai Acuan Cita Ideal}

Islam harus dijadikan sebagai acuan cita ideal pendidikan Islam sekalipun kedua gerakan Islam Muhammadiyah dan NU tidak secara implisit menyebutkan Islam sebagai bagian dari namanya, namun semua tahu bahwa keduanya berstatus sebagai organisasi masa Islam serta berperan sebagai gerakan sosial keagamaan yang beraqidah Islam. Hal ini tercermin dalam tujuannya "menegakkan dan menjunjung Tinggi Agama Islam, sehingga terwujud masyarakat utama, adil, makmur dan diridhoi Allah SWT.

Dari rumusan tujuan tersebut kedua organisasi Islam menempatkan Islam sebagai acuan cita idealnya, yang tidak mungkin diganggu gugat.Pendidikan yang bernaung dibawah panji kedua organisasi tersebut bukan semata-mata untuk membantu menumbuhkan lapisan mobilitas antar lapisan umat Islam atau masyarakat yang lebih luas, namun sekaligus sebagai cagar yang menjamin terselamatkannya struktur dan indentitas dari generasi.Cristoper J.Lucas menyatakan pendidikan adalah markas penyimpan kekuatan luar biasa, yakni memiliki akses keseluruhan aspek kehidupan, memberi informasi yang paling berharga mengenai pegangan hidup masa depan serta membantu generasi dalam mempersiapkan kebutuhan esensialnya untuk menghadapi perubahan. ${ }^{14}$

\section{Berorientasi Kualitas Bukan Populis}

Untuk melakukan reoreantasi pada lembaga pendidikan Islam perlu diarahkan pada pemberian ruang gerak yang seluas-luasnya pada fungsi esensial dari pendidikan.Dalam arti pelaksanaan pendidikan bukan pada asas kepentingan mendapatkan popularitas di tengah masyarakat tetapi yang jauh lebih penting dari itu adalah bagimana roh pendidikan dapat diinternalisasikan dalam diri insan akademik sehingga memiliki kualitas excellent yang dapat bersaing dalam tingkatlokal, nasional dan internasional. Sederhananya pendidikan bukan berbicara kuantitas akan tetapi yang paling penting adalah kualitas yang dimilikinya, karena pendidikan yang diselenggarakan selama ini kebanyakan lebih kepada pemenuhan kebutuhan tanpa harus memikirkan output pada lembaga pendidikan tersebut. Sebagai bahan studi kajian, ormas terbesar di Indonesia NU dan Muhammadiyah yang sudah mendapatkan pengakuan public (public trust) harus mampu meningkatkan kualitas pelaksanaan pendidikan, baik dari segi kurikulum, manajemen pengelolaan, sarana dan prasarana yang mendukung kelancaran kegiatan pendidikan. Dengan demikian pendidikan Muhammadiyah dan NU tidak sekedar menikmati pengakuan peran kuantitatif dari masyarakat dan pemerintahan,

${ }^{14}$ LihatIkhlas, "Konsep Pengembangan Pendidikan Islam Modern” Jurnal Ilmiah Kreatif, Volume XII Nomor 2 edisi Juli 2015 Ber-ISSN 0216-7794: IAIM Bima,2015 
akan tetapi lebih menghasilkan generasi yang berkualitas untuk menembus nobel tingkat internasional.

\section{Pendidikan Islam Perlu Pilot Project}

Perguruan Tinggi Islam seperti Universitas Muhammadiyah maupun Perguruan Tinggi umum lainnya harus mampu membuat atau merancang sebuah pilot project yang handal secara spiritual Islami, berwawasan keilmuan dan empirik khusus yang pendidikan tinggi Islam dan spiritual keagamaana khusus pendidikan tinggi umum lainnya, sehingga bisa melahirkan hasil yang hatinya dilimpahi suasana iman, dan dalam pikiranya dilimpahi ilmu pengetahuan serta ditangannya tersimpan sejuta kecakapan. Tanpannya piloc project semacam ini mendapat dukungan dari berbagai pihak, apalagi kondisi politik dan perekonomian pendukungnya sangat memungkinkannya, namun untuk merealisasikannya perlu persiapan yang benar-benar matang, terutama jika pilot project berskala internasional seperti yang dilakukan oleh Muhammad Naquib Al-Attas melalui ISTC di Malaysia membuat sebuah lembaga pendidikan yang memiliki haluan Islam modern yang didukung oleh kalangan cendekiawan Muslim dan pemerintah setempat.

Dengan jumlah pendidikan Islam yang diselengarakan oleh Muhammadiyah dan NU yang begitu besar, sebelum memulai pilot project perlu assessmen, hasilnya disebut feasibility study, mendesain perencanaan serta melakukan perencanaan dengan persiapan yang matang. sebagai langkah awal bisa dilaksanakan pada Perguruan Tinggi Islam yang bernaung dibawah Muhammadiyah dan Nahdatul Ulama. Dalam pelaksanaan pilot project selain mempersiapkan biaya yang cukup, keberanian dan terbebas dari ikatan-ikatan formalitas yang bersifat birokrat seperti penghargaan dan pengakuan perlu di hindari oleh Perguruan Tinggi tersebut. Karena tersebut dapat menganngu konsentrasi visi, misi dan tujuan pilot project yang sedang dilaksanakan.

\section{Peran Universitas Muhammadiyah Kupang Terhadap Pengembangan Pendidikan Islam}

Eksistensi Universitas Muhammadiyah Kupang merupakan salah satu Perguruan Tinggi Islam yang memiliki peran yang sangat urgen dalam mengembangakna pendidikan Islam di Nusa Tenggara Timur.Dengan menujukan beberapa peran nyata yang dilakukan oleh Perguruan Tinggi Muhammadiyah Kupang, maka perguruan tersebut harus meningkatkan kualitas dan kuantitas terhadap pengembangan pendidikan Islam.Beberapa peran yang dilakukan oleh Perguruan Tinggi Muhammadiyah Kupang dalam mengembangan pendidikan Islam antara lain adalah meningkatkan kualitas dakwah amal ma'ruf nahi munkar, meningkatkan kualitas pembinaan dan pengajaran, kualitas penelitian dan pengabdian masyarakat, meningkatkan kualitas dan kuantitas kerjasama dibidang 
agama, politik, ekonomi dan lainnya. Dengan beberapa bentuk peran yang lakukan tersebut Perguruan Tinggi Muhammadiyah Kupang harus terus mengembangkan inovasi dan kreatifitas dalam mengembangankan pendidikan Islam.salah satu peran yang harus dilakukan adalah meningkatkan kerjasama dengan pihak internal kampus seperti adanya kesamaan tujuan untuk mencapai visi, misi Perguruan Tinggi tersebut. Apabila sudah tercapainya kesamaan untuk mencapai visi, misi Perguruan Tinggi tersebut maka apapun yang dilakukan dapat tercapai dengan sempurna. Berikut ini tugas yang harus dikembangankan oleh Perguruan Tinggi Muhammadiyah Kupang adalah

\section{a. Pembinaan Karakter Secara Terpadu}

Untuk mencapai kesamaan pendapat dan pemahaman dalam mencapai visi, misi dan tujuan Perguruan Tinggi Islam perlu adanya pembinaan karakter secara terpadu yang harus dilakukan oleh pimpinan Perguruan Tinggi tersebut. Senada dengan pendapatnya Lickona (1991) yang dikutip Muhaimin dalam buku Pengembangan Kurikulum Pendidikan Islam ${ }^{15}$ mengatakan bahwa;Untuk membina keimanan peserta didik diperlukan pengembangan ketiga-tiganya secara terpadu yaitu pertama moral knowing yang meliputi 1) Moral Awareness, 2) Knowing Moral values, 3) Perspective-taking, 4) Moral Reasoning, 5) Decision Making, 6) Self- Knowledge. Kedua Moral felling meliputi: 1) Conscience, 2) Self-esteem, 3) Empathy, 4) Loving the Good, 5) Self-Control, 6) Humality. Ketiga Moral Action meliputi: 1) competence, 2) Will, 3) Habit.

Pada tataran Moral Action, agar peserta didik terbiasa (habit), memiliki kemauan (will) dan Kompeten (competence) dalam mewujudkan dan menjalankan nilai-nilai keimanan tersebut, maka diperlukan penciptaan suasana religious disekolah dan diluar sekolah. Hal ini sebabkan karena nilai-nilai keimanan melekat pada diri peserta didik kadang-kadang bias terkalahkan oleh godaangodaan setan baik berupa jin dan manusia maupun budaya budaya negatif yang berkembang disekitarnya. Karena itu bisa peserta didik suatu hari sudah kompeten dalam menjalankan nilai-nilai keimanan tersebut, pada saat yang lain menjadi tidak kompeten lagi. Dalam sebuah hadis Nabi Saw dinyatakan bahwa "al-iman yazid wa yanqush " Iman itu bisa bertambah dan bisa berkurang. ${ }^{16}$ Dengan memberikan pembinaan secara terpadu ketiga dimensi tersebut pemahaman keagamaan atau suasana keagamaan dapat tercipta dengan baik dilingkungan Perguruan Tinggi Islam, dan apabila telah dibangun pemahaman keagamaan yang sudah matang dalam setiap individu yang ada di Perguruan Tinggi tersebut maka semua tindakan termasuk untuk melakukan pengembangakan pendidikan agama

\footnotetext{
${ }^{15}$ Muhaimin, Pengembangan Kurikulum Pendidikan Agama Islam; Bandung: PT. Remaja Rosdakarya,2010) 59.

${ }^{16}$ Muhaimin, Pengembangan Kurikulum Pendidikan Agama Islam...,59-61.
} 
Islam dimana saja meraka berada pasti bisa dilakukan walaupun dengan sebuah nasihat yang baik untuk mahasiswa dan masyarakat yang ada disekitarnya.

Peran dosen dalam mengembangkan pendidikan Islam sangatlah penting dalam sebuah perguruan Islam karena dosen adalah salah satu sumberdaya manusia yang perlu di tingkatkan kualitasnya, sebab dari dosen tersebutlah, pendidikan Islam dapat berkembang, oleh karena itu, pimpinan Perguruan Tinggi harus benar-benar memikirkan kualitas para pendidik atau dosen yang ada dilingkungan perguruan tingginya. Sejalan dengan Pernyataan Anies Baswedan mengatakan bahwa:"Kemajuan suatu bangsa terletak pada kualitas dari sumber daya manusia yang dimiliki negara tersebut. Berbicara mengenai kualitas sumber daya manusia berkaitan erat dengan pengembangan pendidikan. Menteri Pendidikan dan Kebudayaan (Mendikbud) Anies Baswedan menyampaikan tiga strategi pengembangan pendidikan saat diwawancarai Tempo TV, di kantor Kementerian Pendidikan dan Kebudayaan (Kemendikbud), menjelaskna bahwa "Bila tiga strategi ini dapat dijalankan dengan baik, maka akan tercipta ekosistem yang baik dalam dunia pendidikan, ketiga strategis tersebut adalah 1) Pengembangan Guru/Dosen, 2) Memperkuat peran dan kerjasama orangtua dan masyarakat, 3). Melibatkan para siswa (mahasiswa) sebagai upaya menciptakan suasana yang menyenangkan dalam proses belajar mengajar ". ${ }^{17}$

\section{b. Menciptakan Suasana Religius pada Lingkungan Perguruan Tinggi}

Perguruan Tinggi Islam adalah salah satu Perguruan Tinggi yang selalu bernaung dan berpedoman pada al-qur'an dan hadits, sehingga setiap keputusan dan tindakan yang diambil harus berdasarkan pada al-qur'an dan hadits. Kenyataana ini seharus dilakukan oleh semua Perguruan Tinggi Islam maupun Perguruan Tinggi umum yang mayoritas pengelolahnya adalah umat muslim. Karena salah satu tujuan pendidikan adalah memanusiakan manusiamenjadi manusia yang terbaik dimata Allah, manusia dan alam semesta.Untuk menciptakan manusai yang terbaik perlu adanya pembinaan dan bimbingan pada peserta didik/mahasiswa secara kontinyu dan tersistem baik diluar kelas maupun didalam kelas dan perlu ada kerjasama yang baik antar mahasiswa/warga sekolah/kampus dan tenaga kependidikan yang ada didalamnya. Senada dengan Pendapat Anies Baswedan sebut sejalan dengan pendapat Muhaimin mengatakan bahwa: Untuk membentuk peserta didik menjadi manusia yang beriman dan bertakwa kepada tuhan yang maha esa serta berakhlak mulia ternyata tidak bias hanya mengandalkan pada mata pelajaran agama yang hanya 2 jam pelajaran atau 2 sks, tetapi perlu pembinaan secara terus menerus dan berkelanjutan diluar jam pendidikan agama, baik didalam kelas maupun diluar kelas atau diluar sekolah.

${ }^{17} \mathrm{http} /$ www.Seno Hartono.go.id Kemendikbud "Strategi Pengembangan Pendidikan" diakes 31 Desember 2014 
Bahkan diperlukan kerjasama yang harmonis dan interaktif diantar warga sekolah dan para tenaga kependidikan yang ada didalamnya.Perguruan Tinggi Islam perlu memperhatikan hal tersebut, karena tanpa adanya penciptaan suasanana keagamaan dilingkungan Perguruan Tinggi maka Perguruan Tinggi tersebut dapat dikatakan tidak memberikan sumbangsih yang berharga bagi pengembangan pendidikan Islam untuk kejayaan Islam kedepan. Menciptakan suasana religus pada lingkungan Perguruan Tinggi berarti Perguruan Tinggi tersebut telah memberikan peran yang sangat berarti bagi pengembangan pendidikan Islam lebih-lebih pada lingkungan masyarakat Islam minoritas. ${ }^{18}$

Pernyataan pakar pendidikan Islam tentang perlunya membentuk manusia yang beriman dan bertakwa serta berakhlak mulia tersebut perlu dilaksanakan oleh Perguruan Tinggi baik Perguruan Tinggi Islam maupun Perguruan Tinggi umum lainnya.Membentuk manusia yang beriman dan bertakwa serta berakhlak mulia khususnya pada program studi pendidikan umum lainnya tidak cukup dengan mengandalkan mata kuliah pendidikan agama Islam.Akan tetapi yang perlu diperhatikan adalah pembinaan keagamaan yang secara berkelanjutan perlu diperhatikan oleh pimpinan Perguruan Tinggi tersebut sehingga terciptanya suasana religus dalam lingkungan Perguruan Tinggi yang dimilikinya.

\section{c. Islamisasi Ilmu Pendidikan}

Berdasarkan hasil penelitian penulis menemukan bahwa Perguruan Tinggi Muhammadiyah Kupang melakukan tahapan awal untuk memperkenalkan kepada seluruh mahasiswanya dalam mempelajari program Bahasa Arab dan Al-Islam Kemuhammadiyahan baik yang beragama Islam maupun yang non-muslim, dengan tujuan agar mahasiswa tersebut dapat mengenal dan mengetahui bahwa Bahasa Arab adalah salah satu bahasa pengantar internasional yang penting untuk dipelajari setelah bahasa Inggris, disamping untuk memperkenalkan sebagai bahasa pengantar, bahasa Arab adalah bahasa asli dalam kitab-kitab semua agama baik agama Islam maupun agama non-muslim. Sedangkan untuk mata kuliah AlIslam dan Kemuhammadiyah adalah salah satu mata kuliah wajib yang harus diprogramkan oleh siapa saja yang masuk di Perguruan Tinggi Muhammadiyah dimanapun berada, karena mata kuliah tersebut adalah mata kuliah yang diamanahkan oleh Pimpinan Pusat Muhammadiyah, hemat penulis melalui mata kuliah tersebut mahasiswa khususnya mahasiswa muslim agar dapat membekali dirinya dengan ilmu-ilmu pendidikan Islam sehingga mahasiswa tersebut tidak mudah melupakan Allah sebagai Tuhan yang Maha Kuasa yang telah menciptakannya. Sedangkan untuk mahasiswa non-muslim, hemat penulis agar meraka diperkenalkan bahwa agama Islam adalah agama yang rahmatallil

\footnotetext{
${ }^{18}$ Muhaimin, Pengembangan Kurikulum Pendidikan Agama Islam...,59.
} 
aalamin, agama yang toleran bukan agama yang intoleran sebagaimana yang dipahami sebagaian orang bahwa Islam adalah agama yang intoleran.

Penulis dapat menyimpulkan bahwa Perguruan Tinggi Muhammadiyah Kupang sudah berusaha mengislamkan ilmu pendidikan umum kedalam pendidikan Islam atau Islamisasi ilmu pendidikan melalui pendidikan bahasa arab dan al-Islam dan kemuhammadiyahan, akan tetapi hal ini baru hanya sebatas memperkenalkan belum pada tataran implementasi secara nyata pada mata kuliahmata kuliah pada program studi lainnya misalnya program studi biologi, bahasa, ekonomi, perikanan, social dan lainnya. Menurut hemat penulis apabila ilmu-ilmu tersebut dapat dikaitkan dengan ilmu Islam atau sebaliknya, teori-teori pada ilmu tersebut dikonfirmasikan pada al-qur'an dan hadis atau ijmah para ulama yang shahih, maka nyatalah Islamisasi ilmu atau sain Barat kedalam ilmu pendidikan Islam.

Salah satu tugas yang paling urgen Perguruan Tinggi Islam khususnya Perguruan Tinggi Muhammadiyah Kupang yang memiliki sejumlah program studi umum adalah Islamisasi ilmu pendidikan, hemat penulis dengan mengislamisasi ilmu-ilmu pendidikan barat kedalam ilmu pendidikan Islam suasana pengembangan pendidikan Islam dilingkungan Perguruan Tinggi tersebut akan terasa nyata pengembangan pendidikan Islamnya.Sebagai tawaran penulis untuk Perguruan Tinggi Islam dalam mengembangkan pendidikan Islam adalah ada dua cara untuk mengembangkan ilmu pendidikan Islami atau Islamisasi ilmu pendidikan, pertama; cara deduksi kita mulai dari teks wahyu/al-qur'an atau sabda rasul, lantas ditafsirkan, dari sini muncul teori pendidikan pada tingkat filsafat;teori itu dieksperimenkan, dari sini akan muncul terori pendidikan pada tingkat ilmu (sain). Uraian lebih lengkap tentang proses membuat teori tersebut dapat dilihat pada buku epistemology untuk pengembangan ilmu pendidikan Islam $^{19}$. Cara deduksi memang menjamin teori teori yang diproduksi tidak akan menyimpang dan berlawanan dengan ajaran Islam. tetapi cara ini amat lama, mahal dan sulit.Cara kedua adalah cara induksi-konsultasi yaitu mengambil teori yang sudah ada baik dari barat maupun dari timur setelah itu dapat dikonsultasikan ke Al-Qur'an dan Hadits, jika tidak berlawanan, maka teori tersebut dapat didaftarkan kedalam khazanah ilmu pendidikan Islami. ${ }^{20} \mathrm{Jadi}$ kesimpulannya bahwa Islamisasi ilmu pendidikan adalah salah satu tugas yang wajib dikembangkan oleh ilmuan-ilmuan Islam yang ada pada Perguruan Tinggi Islam karena dengan mengIslamisasi sain/ilmu pendidikan Barat kedalam Islam, maka para ilmuan muslim dapat menguasai atau paling tidak dapat bersaing dengan para pemikir dan pakar-pakar pendidikan dan non pendidikan barat yang

\footnotetext{
${ }^{19}$ Ahmad Tafsir, Epistemologi Untuk Pendidikan Islam (Bandung: Fakultas Tarbiyah IAIN Bandung, 1995), 96.

${ }^{20}$ Ahmad TafsirFilsafata Pendidikan Islam (Bandung PT. Remaja Rosdakarya,2010), 23.
} 
sejak saat ini menguasai dunia, padahal apabila dilihat dari sejarah Islam telah menguasai dunia selama 15 abad baik dunia pendidikan maupun non pendidikan.

\section{d. Mengembangkan Fakultas Agama Islam}

Untuk mewujudkan pengembangan pendidikan Islam yang luas dan lebih nyata di Nusa Tenggara Timur, hal yang pertama yang harus dipikirkan oleh Pimpinan Universitas dan Fakultas adalah bagimana cara mengembangan Fakultas Agama Islam kearah yang lebih baik dan terarah. karena Fakultas Agama Islam adalah rohnya Universitas Muhammadiyah Kupang. Oleh karena itu pengembangan dan peningkatan kualitas Al-Islam dan Kemuhammadiyahan dan bahasa arab harus benar-benar digenjot dengan serius. Apalagi dengan telah didukung dengan laboratorim bahasa yang sudah memadai, tinggal eksen dan kesungguhan para pimpinan yang diikuti oleh para dosen yang ada di Fakultas Agama Islam. Hemat penulis bahwa dengan meningkatkan kualitas al-Islam kemuhammmadiyahan dana bahasa arab di Perguruan Tinggi Muhammadiyah Kupang, maka pengembangan pendidikan Islam kedepan di Nusa Tenggara Timur akan lebih nyata dan terpercaya.

Pertama-tama yang harus dilakukan adalah penetapan kesatuan visi, misi antara universitas dan FAI.Kedua, menjadikan wacana keilmuan dan keIslaman sebagai semboyang dalam proses implementasis tri darma Perguruan Tinggi.Ketiga, memberlakukan sentralisasi tanpa menumpuhkan kreativitas, universitas memberlakukan sentralisasi dalam beberapa kebijakan seperti keuangan, pembiayaan dan lain-lain untuk tercapainya efesiensi, namun memberikan keluasan kepada fakultas dalam mengembangkan akademik. Keempat, efektifitas dan efesiensi. Guna peningkatan efektifitas dan efisiensi diberlakukan peranan dan fungsi dosen, zero growth, dan kesejahteraannya.Kelima, transparansi dan responsibiltas.Dalam konteks ini Pimpinan Universitas dan Fakultas memberlakukan kebijakan terbuka.Perpustakaan pendirian lembaga penjamin mutu.Keenam, menuju world class university. Untuk menuju WCU ini, universitas melakukan rekruitmen dosen dengan prestasi TOEFL yang memungkinkan dapat meraih beasiswa diluar negeri, bukan berdasarkan kedekatan hubungan keluarga dan suku. Membuka kelas internasional di FAI yaitu prodi PAI dan Magister Hukum Islam dengan pengantar Arab dan Bahasa Inggris.Menerima mahasiswa internasional dengan hasil MOU atau kerjasama dengan universitas LN (MoU dan LoI FAI dengan PT M'sia).Melakukan akselerasi presentasi dan penulisa artikel ilmiah diforum dan jurnal internasional. ${ }^{21}$

${ }^{21}$ Amsal Bahktiar dan H.M Abdul Fattah Santoso, Penguatan Tata Kelola PTKI Swasta; Inovasi Kelembagaan Dan Manajemen (Jakarta: Direktorat Pendidikan Tinggi,2017), 53-55. 
Disamping keenam upaya diatas dalam kegiatan penelitian dan pengabdian kepada masyarakat, Universitas Muhammadiyah Kupang harus memberlakukan kebijakan pelibatan berbagai unsur mahasiswa dilibatkan melalui penelitian kolaboratif dan terlibat dalam kegiatan mahasiswa seperti kegiatan PKM. Dalam konteks ini pula, kemajuan-kemajuan yang dicapai oleh Perguruan Tinggi Muhammadiyah lainnya dapat diarahkan berdampak pada kemajuan Persyarikatan, misalnya memfasilitas program PPM, PWM, PDM, PCM, PRM dan ortom-ortom dalam Muhammadiyah. FAI berkerjasama dengan majelis tarjih dan majelis tablig PWM. Pelibatan sumber daya manusia (PTM) dalam kepengurusan dan kegiatan PPM, PWM, PDM, PCM, PRM, ortom-ortom dan integrasi program pengabdian kepada masyarakat (LPPM dan Lazizmu) dengan pemberdayaan C \& R.

\section{Penutup}

Peran Universitas Muhammadiyah Kupang terhadap pengembangan Pendidikan Islam sangatlah urgen pada abab ini, karena salah satu yang dapat menyelesaikan masalah dikotomi ilmu pengetahuan sain Barat dan Timur. Untuk menjawab permasalah tersebut minimal Perguruan Tinggi Islam dapat mengembangkan Fakultas Agama Islam lebih berkualitas, menghidupan suasana religious dilingkungan perguruan tinggi, mempertajam kajian dan analisis kitabkitab klasik (Timur dan Barat), Islamisasi Ilmu pendidikan, memberikan bimbingan dan pembinaan secara terpadu kepada semua baik mahasiswa, tenaga pendidik, non pendidik, karyawan, Satpam, cleaning Servis, pengelola kanting dan semua yang terlibat didalamnya dan yang paling penting adalah segala sesuai yang harus dilandaskan pada rujukan yaitu Al-Qur'an, Hadits, dan ijma'.

\section{DAFTAR PUSTAKA}

Ahmad Tafsir, Filsafata Pendidikan Islam, Bandung PT Remaja Rosdakarya, 2010.

Ahmad Tafsir, Epistemologi Untuk Pendidikan Islam, Bandung: Fakultas Tarbiyah IAIN Bandung, 1995.

Ahmad Tafsir,Ilmu Pendidikan Dalam Perspektif Islam, Bandung PT Remaja Rosda Karya, 2006.

Ahmadi, Abu ,Ilmu Pendidikan, Cet.I; Jakarta: Rineka cipta, 2009.

Al-Qardhawi, Yusuf.Pendidikan Islam dan Madrasah terjemahan Bustani A. Gani dan Ahmad, Zainal Ilmu Pendidikan, Jakarta: Bulan Bintang, 2008.

Amsal Bahktiar dan H.M Abdul Fattah Santoso, Penguatan Tata Kelola Ptki Swasta; Inovasi Kelembagaan Dan Manajemen, Jakarta: Direktorat Pendidikan Tinggi.2017

Azra, Azyumardi, Esei-esei Intelektual Muslimdan Pendidikan Islam (Jakarta: Logos Wacana Ilmu, 2008. 
Beni Ahmad Saebani, dkk, Ilmu Pendidikan Islam,Bandung: Cv.Pustaka Setia, 2009.

Departemen Agama RI, Al-Qur'an dan Terjemahnya (Jakarta: Proyek Pengadaan Kitab Suci Al-Qur'an,1992.

http/www.Seno Hartono.go.id Kemendikbud), Rabu, 31/12/2014 diakses tanggal 27 Juli 2017.

Ikhlas, Jurnal Ilmiah Kreatif, Volume XII Nomor 2 edisi Juli 2015 Ber-ISSN 0216-7794: IAIM Bima,2015.

Langgulung Hasan, Beberapa Pemikiran tentang Pendidikan Islam (Bandung: alMa'arif, 1980.

Malik Fadjar, Holistika Pemikiran Pendidikan, Jakarta: Raja Grafindo Persada,2006.

Muhaimin, Paradigma Pendidikan Islam; Upaya Mengefektifkan Pendidikan Agama Islam di Sekolah.Cet. II; Bandung: PT. Remaja Rosdakarya,2009.

Muhaimin, Pengembangan Kurikulum Pendidikan Agama Islam; Bandung: PT. Remaja Rosdakarya, 2010.

Perguruan Tinggi Muhammadiyah Kupang, Sekilas Profil Perguruann Tinggi Muhammadiyah Kupang. 2013.

Tobroni, Pendidikan Islam; Paradigm Teologis, Filosofis Dan Spiritualitas, Malang: UMM press Malang,2008.

Zainuddin Achied, Kiprah Perjuangan Muhammadiyah Nusa Tenggara Timur (sebuah catatan sejarah tahun 1935-2010), Kupang: UM Kupang Press, 2011. 